Ophthalmic Res. 1976;8:I-VI

\title{
Contents, Vol. 8, 1976
}

\section{Contents}

No.l

Editorial

1

Toussaint, D.: Ocular and Meningial Vessel Embolization by Albumin Microspheres.

A Histological Investigation in Man and Animals 2

Kaskel, D.; Edelmann, U.; Ziesmer, W., and Mergelsberg, M.: Osmotic Pressure

Variations in the Aqueous Humour and their Influence on Outflow Facility .

Barishak, Y.R.; Barr-Nea, L., and Messer, Y.: Effect of Chloroquine upon the

Retinal Pigment Epithelium in Organ Culture Conditions 17

Cotlier, E. and Carlin, R.: Lens Hexosaminidases: Purification and Properties 25 Lerche, W.

andBeeger, R.: Ultrastructure of the Outer Nuclear Layer of the Rabbit

Retina following Coagulation with the Ruby Laser 34

Rothstein, H.; Van Buskirk, R., and Reddan, J.: Hypophysectomy Inhibits Wound

Hyperplasia in the Adult Frog Lens 43

Maisel, H.; Perry, M.; Alcalá, J., and Waggoner, P. R.: The Structure of Chick Lens

Water-Insoluble Material 55

Schønheyder, F.; Ehlers, N,, and Hust, B.: Transport of Amino Acids and Related

Compounds from Plasma to Aqueous Humour in Man

64

No. 2

Bonaventure, N.; Wioland, N,. and Karli, P.: Brightness Coding of White and Chro matic Stimuli in the Chicken, Suslik, and Rat Electroretinogram: Relation to

Light Adaptation 81

Krejci, L.; Praus, R., and Brettschneider, L: Intraocular Penetration of Cysteine from Hydrophilic Gel Contact Lenses through the Intact, Epithelium-Denuded and Lime-Burned Cornea 93

Ikui, H.; Uga, S., andKohno, T.: Electron Microscope Study on Astrocytes in the Human Retina Using Ruthenium Red 100

Mester, U.; Heimig, D., and Dardenne, M.U.; Measurement and Calculation of Refraction in Experimental Keratophakia with Hydrophilic Lenses 111

Marak, G.E.,jr.; Font, R.L., andAlepa, F.P.: Experimental Lens-Induced Granulomatous Endophthalmitis: Passive Transfer with Serum

117

Cioli, S.: Glycogen Content and Phosphorylase Activity in Normal and Cataractous

Human Lenses 121

Holtmann, H. W.; Stein, H.J., and Dardenne, M. U.: Experiments on Corneal Pres ervation (Short-Time Storage) 124

Greiner, J. V. and Chylack, L. T., jr.: Anatomy of the Experimental 'Hypoglycemic' Cataract in the Rat Lens 133

Laszczyk, W.A.; Naciqzek-Wieniawska, A., and Witowska-Veit, M.: Changes in the Visual System of Rabbit Fetuses after Thalidomide Administration ... 146 
Oosterhuis, J.A.; Sie, S.H.; Nolen, W.A.; Versteeg, J., andJeltes, I.G.: Therapy of Herpetic Keratitis with a Combination of Poly I.- C and Idoxuridine .... 152

Varia 160

IV

Contents

No. 3

Praus, P.; Brettschneider, I., and Krejci, L.: Ethylenediamine tetraacetate: Its

Release from Hydrophilic Gel Contact Lenses, Intraocular Penetration and

Effect on Calcium in the Cornea after Lime Burns 161

Barishak, Y.R.; Beemer, A.M.; Egyed, M. N.; Shlosberg, A. , and Eilat, A.: Histology

of the Retina and Choroid in Ducklings Photosensitized by Feeding Ammi

majus Seeds 169

Wildberger, H.; Van Lith, G,. and Mak, G.: Comparative Study of Flash and Pat

tern Evoked VECPs in Optic Neuritis

179

Stjernschantz, J.; Uusitalo, R.; Palkama, A.; Niskanen, H., and Johansson, G.: Effect of

Stimulation of the Oculomotor Nucleus on Intraocular Pressure, Outflow Facility and Protein

Concentration of the Aqueous Humour in Rabbits . 186

Orzalesi, N.; Sorcinelli, R., and Binaghi, F.: Glucose-6-Phosphate Dehydrogenase

in Cataracts of Subjects Suffering from Favism 192

Scholz, R.; Kaskel, D., and Hockwin, O.: Effect of Unilateral Pressure Ischaemia

on the Carbohydrate Metabolism in Ocular Tissues 195

Aviner, Z.; Henley, W.L.; Leopold, I.H., and Okas, S.: Cellular Hyperresponsiveness to Corticosteroids in Open-Angle Glaucoma: Steroid-Induced Leucocyte Migration Inhibition 202

Mosebach, K.-O.; Lippert, U.; Dardenne, M. U., and Pfeiff, B.: An Electrophoretic System for Analyzing Labelled Drug-Binding Protein in Eye Tissues .... 207

Lerman, S.; Kuck, J.F.,jr.; Borkman, R.F., andSaker, E.: Induction, Acceleration and Prevention (in vitro) of an Aging Parameter in the Ocular Lens .... 213

Ohrloff, C; Holstege, A., and Hockwin, O.: Enzymes Involved in the Glycogen

Metabolism of the Lens in Relation to Age, Topographic Distribution, and

Association with Water-Soluble Proteins 227

Sperling, St.: Toxicity of DMSO to Bovine Corneal Endothelium 233

No. 4

Inwang, E.E.; Henderson, C.T.; Bath, P.E., and Mauge, C.E.: y-Aminobutyric

Acid: Possible Role as a Neuro-Ophthalmic Modulator 241

Francois, J.; Victoria-Troncoso, V.; Maudgal, P. C; Victoria-lhler, A., and Uvijls, H,:

Goniocytes in Tissue Culture. Microcinematography and Vital Staining before

and after Cortisone Action 248

Blumenthal, M.; Yankelev, S., and Dikstein, S.: Method for Antiglaucoma Drug

Screening on Rabbits 259

Vrabec, F.; Smelser, G.K., and Ozanies, V.: Rabbit Cornea Damage Induced by

Alloxan. An Experimental Study 262

O’Donnell, F.jr. and Green, W.R.: Naevus of the Optic Nerve 276

Glässer, D.; Iwig, M.; Ansorge, S., and Fischer, C: Investigations on the Differ

entiation of Bovine Lens Epithelial Cells in vitro 283

Waggoner, P.R.; Lieska, N.; Alcalá, J., and Maisel, H.: Ontogeny of Chick Lens 
ß-Crystallin Polypeptides by Immunofluorescence 292

Contents V

Welge-Lüssen, L.; Stadler, G., and Cattepoel, H.: Postmorgem Changes of Glycolytic Metabolite Levels and Amino Acids in the Aqueous and Vitreous . . . 302 Hazlett, L.D.; Rosen, D., and Berk, R.S.: Experimental Eye Infections Caused by Pseudomonas aemginosa $\quad 311$

Varia 319

No. 5

Hockwin, O.; Hahn, U., and Swanson, A. A.: Studies on Proteolytic Activity in Bovine Lenses with Ageing. II. The Endopeptidases 321

Singer, L.; Romem, M.; Egyed, M.N.; Shlosberg, A., andEilat, A.: MethoxsalenInduced Ocular Lesions in Ducks 329

Lerman, S. and Borkman, R.: Spectroscopic Evaluation and Classification of the Normal, Aging, and Cataractous Lens. (With 1 color plate) 335

Babkoff, H.: Quantitative Study of Two-Pulse b-Mave Recovery Functions . . 354

Pram, R.; Krejcí, L.; Brettschneider, I., and Miková, M.: Use of Hydrophilic Con tact Lens for Application of IDU. Study on Rabbits with Artificial Cornea

Lesions and Herpetic Keratitis 362

Haeringen, N.J. van and Glasius, E.: Characteristics of Acid Hydrolases in Human Tear Fluid 367

Stárka, L. and Obenberger, J.: Testosterone Metabolism in Various Tissues of the Intact and Inflamed Rabbit Eye $\quad 374$

Zigler, J.S.,jr.; Sidbury, J.B.,jr,; Yamanashi, B.S., and Wolbarsht, M.: Studies on Brunescent Cataracts. I. Analysis of Free and Protein-Bound Amino Acids 379 Stein, P.J.; Henkens, R.W.; Yamanashi, B.S., and Wolbarsht, M.: Studies on Brunescent Cataracts. II. Fluorescence Studies on Normal and Brunescent Lens Proteins 388

Bíjsterveld, P.O. van andLeppink, G.J.: Fluorometholone and Dexamethasone . 395 No. 6

Worgul, B.V.; Srinivasan, B.D., and Merriam, G.R. jr.: The Conjunctival Epi thelium. I. Methods for Preparing Isolated Whole-Mounts of the Rat Con junctival Epithelium 401

Wickham, M.G. and Binder, P.S.: Evaluation of Corneal Endothelial Damage using Correlated Microscopy Techniques (With 1 color plate) 407

Francois, J.; Maudgal, P. C, and Victoria-Troncoso, V.: Experimental Keratitis Sicca. The Corneal Epithelium at the Transmission and Scanning Electron Micro scope 414

Kandel, G.I.; Bedell, H.E., and Fallon, J.H.: Near-Final Scotopic Thresholds in Normal Eyes and in the Dominant Eyes of Amblyopes 425

Schütte, E. and Reim, M.: Fructose Metabolism of the Cornea

Van Dalen, J.T. W.: Flash-Induced Nystagmus in Man 438 VI

Contents

Harding, C. V.; Susan, S., and Murphy, H.: Scanning Electron Microscopy of the Adult Rabbit Lens 443 
Bando, M.; Ishii, Y., andNakajima, A.: Changes in Blue Fluorescence Intensity and Coloration of Human Lens Protein with Normal Lens Aging and Nuclear

Cataract $\quad 456$

Short Communication

Ono, S.; Hirano, H.; Koizuka, T., and Obara, Y.: 5-Hydroxytryptophan and Histidine Decarboxylase Activity in the Senile Cataractous Lens 464

Varia 467

Author Index 468

Subject Index 